\title{
Investigating the utilisation of the Micro-Functions of Bahasa Melayu by English Teachers
}

\author{
NOOR HAYATI ROMLI \\ School of Language Studies \& Linguistics, \\ Faculty of Social Sciences \& Humanities, \\ Universiti Kebangsaan Malaysia, Malaysia \\ missusyati@gmail.com \\ MOHD SALLEHHUDIN ABD AZIZ \\ School of Language Studies \& Linguistics, \\ Faculty of Social Sciences \& Humanities, \\ Universiti Kebangsaan Malaysia, Malaysia \\ PRAMELA KRISH \\ School of Language Studies \& Linguistics, \\ Faculty of Social Sciences \& Humanities, \\ Universiti Kebangsaan Malaysia, Malaysia
}

\begin{abstract}
The controversy over the use of first language (L1) in the second language (L2) classroom has been discussed extensively by numerous scholars in which they either advocate or reject the utilisation of L1 in the target language (TL) classroom. Although the proponents of the monolingual approach argued that there are many disadvantages of utilising the L1, they have yet to present empirical findings to demonstrate that L1 could ultimately hinder the L2 learning. In most L2 classrooms, teachers and students often share similar experiences of L1 utilisation, including in English language classroom in Malaysia. Therefore, it is common for teachers to feel the inclination to use L1 when the other options have failed to explain something during the lessons. A considerable number of local and international studies have pointed out on the wide range of L1 use by L2 teachers. Thus, this study intended to investigate the specific utilisation of micro-functions of L1 (Bahasa Melayu) by English (L2) teachers. A total of 899 English teachers from Pahang were randomly selected to respond to a survey questionnaire which consists of 43 items that represent a myriad functions of Bahasa Melayu (BM). The findings of the study showed that the majority of the respondents utilised a significant number of micro-functions of BM to teach English particularly to assist them in delivering the content of the lessons while its usage was so significant for classroom management and social and interpersonal reasons. The study proposes a need for proper guidelines on how and when teachers should use L1 in L2 teaching.
\end{abstract}

Keywords: First Language; Second language; Bahasa Melayu; English Teachers

\section{INTRODUCTION}

L1 is defined as the first language a person learned, and the most proficient with or the language that is used most often, (Unesco 2003). Besides, the first language (L1) is also known as the mother tongue (MT). A lot of contemporary linguists and educators typically use the term L1 to signify the first language or the mother tongue, while the term L2 (second language) refers to the second or foreign language that is being studied, (Nordquist 2020). In relation to the context of this study, L1 refers to Bahasa Melayu, the language spoken by one of the predominant groups in Malaysia, the Malays as well as the language spoken widely spoken by Malaysians while English is the second language (L2) of the country.

After independence from the British, BM managed to secure the status as the national language in Malaysia (Hazita Azman 2016). The importance of BM as the national language can be observed in the context of Malaysian schools. For the government schools, the medium 
of instruction is BM, with English as the compulsory subject. Although English acts as the second language (L2) of the country, it plays a pivotal role for social, business and judiciary functions especially in metropolitan areas (Asmah 1982). Meanwhile, for the vernacular schools, the main language used is either Mandarin or Tamil with Bahasa Melayu and English are taught as the compulsory subjects.

In relation to the role of $\mathrm{L} 1$ in second language learning, the controversy over its use in the L2 classroom has been extensively discussed among teachers and scholars (Cook, 2001; Fortune, 2012). Those who do not support the use of L1, mainly claim that it deprives the students' opportunity to receive the maximum language input, particularly in learning L2 as a second or foreign language (Krashen 1981). While L1 is seen as detrimental in acquiring a second language, the maximum use of TL is considered paramount in L2 classroom, (Lightbrown \& Spada 2006). It ought to be noted that although there are numerous educationists and scholars who have rejected the integration of L1 in L2 teaching and learning, the current views have been slowly shifting from absolute rejection towards reevaluating its roles. This happened partly as there has been no empirical evidence recorded to suggest that limiting the use of L1 could improve L2 learning (Eldridge 1996).

By comparison, L1 could also serve as pedagogical, discursive or social reasons on par with L2 functions (Levine 2012). In fact, most of the current theoretical stance recognizes the potential of L1 towards improving L2 learning mainly in linguistic, psychological and social development. The Common Underlying Proficiency (CUP) theory which is proposed by Cummins (2000) strongly endorses the inclusion of L1 in L2 classroom. The CUP theory explains that the ideas formed inside second language learners' brains are originated from a single source, particularly, the language that the learners are most proficient with which is their L1. Thus, it is plausible for teachers to manipulate it especially for better language learning experience for the students.

Meanwhile, Vygotsky's Sociocultural Theory delineates six dynamic functions of L1 in the TL classroom namely as a tool to mediate the L2 learning, facilitate metalinguistic awareness, as private speech; a cognitive tool, a tool for thinking, as a means for learners to interact with each other and as social-mediation and lastly to reduce frustration, (Leung 2005). Besides receiving positive feedback from current theories, L1 is seen as an essential learning instrument in TL classroom. This is particularly essential for early stages of proficiency levels as it facilitates learners' progress in L2 and has direct impact in reducing learners' anxiety during learning process (Auerbach 1993).

\section{MICRO-FUNCTIONS OF L1 IN THE L2 CLASSROOM}

The advocators of bilingual approach have maintained that there are certain roles or functions that L1 could play in the L2 classroom (Namba 2005). These functions can be divided into two categories which are the macro and micro functions. Related functions of L1 on the macrolevel address the language choices within the community while the micro-level deal with functions that happen during interaction between speakers (Namba 2005). The functions of L1 in the macro-level equip students with necessary language skills to survive the social world and to be able to communicate in or outside of community. This study however focuses on the language used by L2 teachers in the language classroom and thus the functions of L1 in terms of micro-level studies are taken into consideration. 
FIGURE 1. Micro-Functions of L1 by Atkinson (1987), Cook (2001), Ferguson (2003), Canagarajah (1995), Sali (2014) and Harbord (1992)

\begin{tabular}{|c|c|c|c|c|c|}
\hline Atkinson (1987) & Cook (2001) & Ferguson (2003) & Canagarajah (1995) & Sali (2014) & Harbord (1992) \\
\hline Eliciting language (all levels) & $\begin{array}{c}\text { Convey meaning :words, sentences or } \\
\text { language functions }\end{array}$ & Curriculum access & Content transmission & Explaining aspects of English & To facilitate teacher-student communication \\
\hline Checking comprehension (all levels) & $\begin{array}{l}\text { Teacher use of L1 to covey and check } \\
\text { meaning of words and sentences }\end{array}$ & Encourage and elicit pupil participation & Review & Eliciting & $\begin{array}{l}\text { Discussion of classroom methodology during } \\
\text { the early stages of a course }\end{array}$ \\
\hline Giving instructions (early levels) & $\begin{array}{l}\text { Teacher use of L1 for explaining } \\
\text { grammar }\end{array}$ & $\begin{array}{l}\text { Clarify the meaning of certain sections } \\
\text { of text }\end{array}$ & Definition & Reviewing & $\begin{array}{l}\text { Explaining the meaning of a grammatical } \\
\text { item(e.g. a verb tense) at the time of } \\
\text { presentation -especially when the specific } \\
\text { structure does not exist in L1 }\end{array}$ \\
\hline Co-operation among learners & Organization of the class & $\begin{array}{l}\text { Demarcate reading the text from } \\
\text { commentary on it. }\end{array}$ & Explanation/reinforcing & Translating words and sentences & $\begin{array}{l}\text { Giving instructions for a task to be carried out } \\
\text { by students }\end{array}$ \\
\hline $\begin{array}{l}\text { Discussions of classsoom methodology } \\
\text { (early levels) }\end{array}$ & Teacher use of Ll for organizing tasks & $\begin{array}{l}\text { Management of Classroom } \\
\text { Discourse }\end{array}$ & a) Repetition & Talking about learning & $\begin{array}{l}\text { Asking or giving administrative information such } \\
\text { as timetable changes, etc., or allowing students } \\
\text { to ask or answer these in Ll }\end{array}$ \\
\hline $\begin{array}{l}\text { Presentation and reinforcement of } \\
\text { language (mainly early levels) }\end{array}$ & $\begin{array}{l}\text { Teacher maintenance of discipline } \\
\text { through L1 }\end{array}$ & To discipline a pupil & b) Reformulation & Checking comprehension & $\begin{array}{l}\text { Checking comprehension of a listening or } \\
\text { reading text }\end{array}$ \\
\hline Checking for sense & $\begin{array}{l}\text { Teacher gaining contact with individual } \\
\text { students through the L1 }\end{array}$ & To attend to latecomers & c) Clarification & Managerial & Explaining the meaning of a word by translation \\
\hline Testing & Teacher use of L1 for testing & To gain and focus pupils' attention & d) Exemplification & Giving instructions & $\begin{array}{l}\text { Checking comprehension of structure, e.g. - } \\
\text { How do you say "I've been waiting for ten } \\
\text { minutes" in (L1)?, }\end{array}$ \\
\hline \multirow[t]{15}{*}{$\begin{array}{l}\text { Development of useful learning } \\
\text { strategies }\end{array}$} & & Negotiating task instructions & Negotiating cultural relevance & Managing discipline & $\begin{array}{l}\text { Allowing or inviting students to give a } \\
\text { translation of a word as a comprehension check }\end{array}$ \\
\hline & & $\begin{array}{l}\text { Interpersonal relations in the } \\
\text { classroom }\end{array}$ & Parallel translation & Monitoring & Eliciting vocabulary by giving the $\mathrm{Ll}$ equivalent \\
\hline & & To build rapport with individual pupils & \begin{tabular}{|l} 
Unofficial \\
collaboration
\end{tabular} & Drawing attention & $\begin{array}{l}\text { Ll explanations by students to peers who have } \\
\text { not understood }\end{array}$ \\
\hline & & Create greater personal warmth & Classroom management & Social/Cultural & $\begin{array}{l}\text { Giving individual help to a weaker student, e.g., } \\
\text { during individual or pair work }\end{array}$ \\
\hline & & Encourage greater pupil involvement & Opening the class & Establishing rapport & $\begin{array}{l}\text { student-student comparison or discussion of } \\
\text { work done. }\end{array}$ \\
\hline & & & Negotiating directions & Drawing upon shared expression & To facilitate teacher-student relationship \\
\hline & & & Request help & Praising & $\begin{array}{l}\text { Chatting in } \mathrm{L} 1 \text { before the start of the lesson to } \\
\text { reduce student anxiety }\end{array}$ \\
\hline & & & Managing discipline & & Telling jokes in Ll \\
\hline & & & Teacher encouragement & & To facilitate learning of $\mathrm{L} 2$ \\
\hline & & & Teacher compliment & & $\begin{array}{l}\text { Comparison with } \mathrm{L} 1 \text { through translation (to } \\
\text { make them realize the dangers of translation) }\end{array}$ \\
\hline & & & Teacher commands & & \\
\hline & & & Teacher admonitions & & \\
\hline & & & Mitigation & & \\
\hline & & & Pleading & & \\
\hline & & & Unofficial interactions & & \\
\hline
\end{tabular}

Numerous scholars have outlined various micro-functions of L1, with some who further distinguish them into several domains. However, Ferguson (2003) argued that despite certain categorisations on the L1 role in the L2 classroom, there is no significant consensus about the number of functions or the domains. Figure 1 shows the list of micro-functions of L1 that are proposed or discovered. According to Cook (2001) and Atkinson (1987), L1 could be used in certain circumstances such as to increase students' comprehension, to present new vocabularies, to explain difficult grammatical items and to give instructions. Harbord (1992) suggests the micro-functions of L1 could be utilised by the L 2 teachers in their lessons specially to teach specific language items. He lists 12 functions of L1 to facilitate teacher and student communication. Meanwhile, Canagarajah (1995) divides the L1 functions that he discovered into two major domains which are the classroom management and content transmission. Likewise, Ferguson (2003) classifies them into three primary categories namely the use of L1 as curriculum access, classroom management and interpersonal relation. Similarly, Sali (2014) integrates similar domain in his study by listing out 12 functions. Based on these classifications, 
the micro-functions of L1 (Figure 1) can be categorised into three domains namely to teach lesson content, to manage classroom and for social and interpersonal relations.

Although the issue of using L1 in the L2 classroom has not been discussed openly among L2 teachers, their actual classroom practice regarding the L1 use is reportedly to be different (Engku Haliza et.al 2013). Time constraint and teaching experience may have direct influence over teachers' teaching practice including the use of L1 during the lessons (Jerome 2017). Farrel (2019) stated that there are studies that reveal teachers' stance towards L1 is contrary to their language use in the classroom (Tsagari \& Georgiou 2016; Alrabah, Wu, Alotaibi \& Aldaihani 2016; Imran and Wyatt 2015). As noted in these studies, even though the teachers support the maximum use of L2, their real usage of L1 is far greater than what they perceived. Indeed, they frequently utilised L1 for a number of functions during the teaching process (Tsagari \& Georgiou 2016).

Regarding the context of this study, the utilisation of the L1 in the English classroom is also inevitable. This is because the use of L1 is common when teachers share similar L1 with the students, (Nakatsukasa \& Loewen 2014). English teachers in Malaysia may have the tendency to use BM for specific functions (micro-functions) since majority of them speak BM. Ali Kutty (2011) indicated that random observation at any school in the east coast of Malaysia, would result in the revelation of excessive practice of BM by both English teachers and students for educational and communication purposes. In fact, BM is commonly used amongst English teachers who have to deal with students who are less proficient in the TL. The use of BM was also reported by Parameswaran \& Lim (2018) who investigated teachers' perspectives as well as their actual use of L1 in the English language classroom in rural areas in Malaysia. The results reveal that the teacher resorted to BM for several functions to accommodate the learning needs of a specific group of students. Similarly, as noted in Azelin, Abdul and Aigbogun (2015) it seemed impossible for English teachers to establish an English only classroom as the students faced great difficulty in understanding teachers' TL. Thus, they had to depend on BM to assist these students during speaking, reading and writing activities.

In addition, other studies have revealed important findings in terms of the frequency of L1 use by L2 teachers. For instance, Ma (2016) reported high frequency of L1 use by the teachers' during classroom recordings in her study for pedagogical, classroom control and social relationship. Paker and Karaagac (2015) noted 17 micro-functions of L1 were utilised by 20 English instructors at a university in Turkey with the highest usage related to explaining and providing examples. Shabir (2017) also discovered a significant number of L1 functions used by L2 teachers at a local university in Australia. According to Shabir (2017), L1 was employed for various functions, such as to manage the class, explain words and grammar rules, offer feedback towards students, clarify tasks, as well as demonstrate differences between L1 and L2. Shabir's findings revealed L2 teachers mostly apply L1 to address teaching content.

The findings from the above studies are relatively similar with Noor Azaliya, Asmaa \& Nik Zaitun (2019) who reported the use of BM by a few English teachers. These teachers applied BM mostly to support students' learning such as to repeat something, explain meaning of words and for affective reason. Another study that highlights the specific use of BM by English teachers is Nur Shazwani and Noreiny (2016). They found that 64 teachers admitted employing BM for nine functions which were grouped into three domains namely the curriculum access, classroom management and interpersonal relations. Although Nur Shazwani \& Noreiny's study managed to report the utilisation of BM in terms of the three domains, they did not thoroughly examine the overall micro-functions of L1 that are proposed by various scholars. Least comprehensive findings in terms of the overall micro-functions is also reported by Cakrawati (2019) involving two English teachers in West Jawa, Indonesia. Although she presented the functions into three domains, the small number of functions implies limited roles that L1 could play in L2 classroom. 
Even though there are studies that reported significant improvement with the presence of L1 such as in reading activity (Abdullah, Hazita \& Kemboja (2014), writing quality (Zhang 2018), grammar learning (Mahmud, 2018), and comprehension of specific words (Parameswaran and Lim, 2018), these positive outcomes cannot be used to validate any excessive use of L1 by L2 teachers. The alarming discovery of high frequency use of L1 implies that majority of L2 teachers do not know how to use L1 while teaching English. Hence, it can be assumed that generally teachers do not have awareness or sufficient knowledge on the suitable approach to use L1 in the classroom. One of the primary causes that contributes to this ongoing phenomenon is the absence of standard guidelines to use L1 by the teachers. Ellis and Shintani (2014) noted that, in general L1 is not being featured as an integral part in any L2 teacher's guide. In addition, Lasagabaster (2013) concluded in her study that vast majority of the L2 teachers did not receive sufficient exposure or any training to use L1 in L2 teaching. How can L2 teachers be aware of this issue when the absence of a comprehensive guidelines to use L1 is apparent?

Even though countless studies have been carried out to investigate the use of L1 in the L2 classroom, there have not been a single study that managed to outline detailed commonalities that exist among the micro-functions of $\mathrm{L} 1$, and not to mention producing a comprehensive guidelines of L1 use for L2 teachers. Thus, there is a significant gap in terms of the specific guidelines for L2 teachers to use the micro-functions of L1 in the classroom. For this reason, it is imperative to investigate the overall functions that L1 serves in the L2 classroom specifically in the Malaysia classroom setting. Therefore, this study intends to bridge the gap in the literature by investigating the micro-functions of L1 (BM) that are utilised by L2 (English) teachers in the English language classroom. By revealing the teachers' current use of $\mathrm{BM}$ for specific functions, it can help pave the way for development of future guidelines on the correct and adequate use of BM in the English classroom.

Hence, the main objective of this research is to investigate the utilisation of the microfunctions of BM by English teachers with L2 students. Specifically, the present study intends to discover specific micro-functions of $\mathrm{BM}$ in three major domains, namely content transmission, classroom management, and social and interpersonal.

\section{METHODOLOGY}

This study employs a quantitative research design, based on studies reviewed (Nur Shazwani \& Noreiny 2016; Shabir 2017) particularly to identify the use of L1 by L2 teachers.

\section{RESPONDENTS}

This research was conducted in the state of Pahang Currently, there are 198 secondary schools including national secondary schools (SMK), fully residential schools, sports secondary schools, technical or vocational secondary schools, MARA junior science colleges, Islamic government-aided secondary schools, Islamic secondary schools, and government-aided secondary schools. In 2018, there were a total of 1232 teachers from all of these schools but only the national secondary schools (SMK) were chosen (161 schools) since this study only focused on the teachers' use of BM with L2 learners. A simple random sampling was applied to ensure that "every element in the sample is drawn independently in a random process from the population" (Flick, 2015: 101). For this current study, the national secondary schools were chosen as the majority of respondents would have higher possibility of teaching students who speak BM as their L1. 
The current study involved English language teachers who were teaching L2 students from 11 districts in the state of Pahang. In total, 891 sets of survey questionnaires were delivered either using a courier serviceor by hand to all the respondents. Nonetheless, due to some limitations, only 469 sets of questionnaires were returned to the researcher within the duration of two months.

TABLE 1. Respondents' personal background

\begin{tabular}{lll}
\hline & Category & Frequency \\
\hline Gender & Male & 100 \\
& Female & 369 \\
Toce & Malal & $\mathbf{4 6 9}$ \\
& Chinese & 383 \\
& Indian & 41 \\
& Others & 36 \\
Tge & Total & 9 \\
& $20-29$ & $\mathbf{4 6 9}$ \\
& $30-39$ & 83 \\
& $40-49$ & 177 \\
& $>50-60$ & 134 \\
Service Grade & Total & 75 \\
& DGA 29 & 469 \\
& DGA 32 & 2 \\
& DG 41 & 1 \\
& DG 42 & 165 \\
& DG 44 & 10 \\
& DG 48 & 183 \\
& DG 52 & 104 \\
& Total & 4 \\
& & 469 \\
\hline
\end{tabular}

Table 1 provides descriptive information about teachers' gender, race, age and teaching grade. A total of 469 teachers took part in the study, with 369 of them are females, while 100 are male teachers. Majority of the respondents are Malays ( $n-383)$, followed by Chinese $(n-$ $41)$, Indians ( $n-36)$, and other races $(n-9)$. These teachers whose ages ranged from 20 to 60 years old were in service teaching with grades from DG29 until DG52. DGA29 and DGA 32 refers to teachers that start teaching career with diploma certificates while DG41 and onwards show that teachers begin their career with degree certificates.

TABLE 2. Respondents’ Background: Qualifications, Location, Option

\begin{tabular}{lcc}
\hline Academic Qualification & Degree & 419 \\
& Master & 50 \\
Location of School & Total & 469 \\
& Urban & 156 \\
& Rural & 303 \\
& Others & 9 \\
Option & Total & 469 \\
& Optionist & 315 \\
& Non-optionist & 154 \\
\hline
\end{tabular}

Table 2 shows that 419 of the English teachers have various first degrees while 50 more hold master's degrees. 315 of the respondents are English option teachers, while the remaining 154 are non-option teachers. English option teachers refer to those with qualification in English or related English majors such as Literature and TESOL. Non-option English teachers refer to teachers who are not trained to teach English but are required to teach the subject in the school. During the survey collection period, these teachers were teaching in schools located either in rural areas $(n=303)$ or urban areas $(n=156)$. 
TABLE 3. Respondents' language information: L1 and L2

\begin{tabular}{lcc}
\hline & Language / Dialect & Number \\
\hline L1 & English & 9 \\
& BM & 390 \\
& Chinese Dialects & 35 \\
Punjabi & 3 \\
Tamil & 27 \\
Others & 5 \\
& BI & 438 \\
BM & 16 \\
BM / BI & 4 \\
BM / Chinese & 1 \\
Cantonese & 1 \\
Chinese & 1 \\
Mandarin & 2 \\
Portuguese & 1 \\
Tamil & 3 \\
\hline
\end{tabular}

From Table 3, the L1 for the majority of the teachers is Bahasa Melayu ( $n=390)$, followed by Chinese dialects $(n=35)$, and Tamil $(n=27)$. Lastly, 438 of them admitted that English is their L2, while 16 teachers reported that BM is their L2.

\section{INSTRUMENT}

The original questionnaire for the main research study consists of three sections which are the teachers' perspectives, usage of the micro-functions and the usefulness. The first section was adopted from Noor Hayati (2015), Joanna (2014), Hamze (2008) \& Sipra (2007). Meanwhile, the second and third sections are constructed based on the framework of the study. A total number of 43 items were included in the questionnaire that employed a five-point Likert scale and these items were further arranged into three sections. All the items signify all 43 microfunctions of BM in English classroom. There are 19 items in the first section (Classroom Management), 14 in the second (Classroom Management) and 10 in the last (Social \& Interpersonal) section.

The survey was validated, and piloted with 30 English teachers from four schools in Temerloh, Pahang to test its reliability. The Cronbach's Alpha coefficient was calculated after the piloting process and the reliability test indicated that the Cronbach's Alpha for all items ( $n$ 43) incorporated in the questionnaire (second section) was 0.916. This finding proves satisfactory internal consistency and accuracy of the scale used.

\section{FINDINGS}

The analysis from the surveys reveals crucial findings in terms of the utilisation of the microfunctions of BM by English teachers in three domains namely the Content Transmission, Classroom Management and Social \& Interpersonal. English teachers utilised these functions in all domains to a certain degree. 

DOMAIN

TABLE 4. Teachers' use of the Micro-functions for Content Transmission Domain

\begin{tabular}{clcc}
\hline \multirow{2}{*}{ No } & Items & Mean & Std. Deviation \\
\hline 1 & I use BM to : & 3.38 & 0.94 \\
2 & Revit meanings from students & 2.99 & 1 \\
3 & Translate words and sentences & 3.04 & 1.09 \\
4 & Provide definitions of terms & 3.58 & 0.88 \\
5 & Give explanation/reinforcement of (words/ phrases/ & 3.12 & 0.99 \\
& sentences) through repetition & 3.05 & 0.97 \\
6 & Give explanation/reinforcement of (words/ phrases/ & & 0.9 \\
& sentences) through reformulation & 3.52 & 0.97 \\
7 & Give explanation/reinforcement of (words/ phrases/ & & 0.94 \\
& sentences) through clarification & 3.1 & 0.82 \\
8 & Give explanation/reinforcement of (words/ phrases/ & 3.34 & 0.93 \\
9 & sentences) through exemplification & 3.69 & 1.06 \\
10 & Relate cultural relevance related to the content of lesson & 2.94 & 1.02 \\
11 & Distinguish reading texts & 3.11 & 0.98 \\
12 & Explain about grammatical item & 3.15 & 1.02 \\
13 & Check comprehension of texts that are used in the class & 3.1 & 0.93 \\
14 & Check comprehension of a structure (phrase or sentence) & 3.26 & 0.99 \\
15 & Allow students to give translation in BM & 3.44 & 0.96 \\
16 & Elicit vocabulary by giving the L1 equivalent & 3.04 & 1.02 \\
17 & Present and reinforce a recently taught language item & 3.36 & 3.14 \\
18 & Check for irrelevant / illogical translations & & \\
19 & Introduce learning strategies &
\end{tabular}

The results from this section (Table 4) showed that the majority of the teachers responded positively towards 17 items and were neutral towards two other items (Items $2 \&$ 11). There are 8 items with highest mean values (Items $10,4,7,16,1,18,8$ and 15). Item 10 (Clarify meanings of certain sections of text) shows a mean value of 3.69, Item 4 (Provide definition of terms) with a mean value of 3.58, while item 7 (Give explanation / reinforcement using clarification) and Item 16 (Elicit vocabulary by giving the L1 equivalent) have mean values of 3.52 and 3.44. Mean values of 3.38 and 3.36 for Item 1 (Elicit meanings from students) and Item 18 (Check for irrelevant / illogical translation) indicated positive stance of the teachers towards these functions of BM. Another two items that received very positive responses are Items 9 (Relate cultural relevance related to the content of lesson) and 15 (Allow students to give translation in BM) with mean values of 3.34 and 3.26.

Another important finding is that the teachers showed little interests for items (Items $13,19,5,12,8,14,6,3,17$ ). For instance, Item 13 (Check comprehension of texts that are used in the class), Item 19 (Introduce learning strategies) and Item 5 (Give explanation/reinforcement through repetition) have mean values of $3.15,3.14$ and 3.12 respectively. Similar response is received for Item 12 (Explain about grammatical item) with mean value of 3.11. Meanwhile, Item 8 (Give explanation/reinforcement through exemplification) and Item 14 (Check comprehension of a structure) display similar mean value which is 3.1. Item 6 (Give explanation/reinforcement through reformulation), Item 3 (Translate words and sentences) and Item 17 (Present and reinforce a recently taught language item) have mean values of 3.05, 3.04 and 3.04 respectively. As mentioned earlier, most of the teachers displayed neutral responses towards Item 2 (Review content of text / lesson) and Item 11 (Distinguish reading texts) all with mean values of 3.04, 2.99 and 2.94 respectively. 


\section{MICRO-FUNCTIONS OF BM UTILISED BY THE ENGLISH TEACHERS IN CLASSROOM MANAGEMENT DOMAIN}

TABLE 5. Teachers' Use of the Micro-functions of BM for Classroom Management Domain

\begin{tabular}{llcc}
\hline \multirow{2}{*}{ No } & Item & Mean & Std. Deviation \\
\hline 20 & I use BM to: & 2.64 & 0.937 \\
21 & Introduce the lesson / topic & 2.4 & 0.897 \\
22 & Negotiate/adjust lesson directions & 2.8 & 0.981 \\
23 & Request for help from students & 2.52 & 0.923 \\
24 & Manage students' discipline & 2.88 & 0.981 \\
25 & Give commands & 2.48 & 0.878 \\
26 & Give admonitions / warnings & 2.65 & 0.975 \\
27 & Gain students' attention and focus & 2.78 & 1.038 \\
28 & Discuss classroom methodology with the students & 2.85 & 1 \\
29 & Give instructions for a task to be carried out by students & 2.63 & 0.905 \\
30 & Ask or give administrative information & 2.89 & 1.007 \\
31 & Give individual help to a weaker student & 3.7 & 0.85 \\
32 & Compare between students' work & 2.43 & 0.836 \\
33 & Testing purposes (test/quiz) & 2.14 & 0.788 \\
\hline
\end{tabular}

In this domain, majority of the English teachers agreed on only one micro-function of BM which is item (Item 31-Give individual help to a weaker student) with a mean value of 3.7. Meanwhile, for other thirteen micro-functions, teachers displayed neutral responses. For example, Item 30 (Ask or give administrative information), Item 24 (Manage students' discipline) and Item 28 (Discuss classroom methodology with the students) with mean values of 2.89, 2.88 and 2.85. Next, are Item 22 (Negotiate/adjust lesson directions), Item 27 (Gain students' attention) and Item 26 (Give admonitions/warnings) with mean values of 2.8, 2.78 and 2.65. On the other hand, Item 20 (Monitor students' progress), Item 29 (Give instruction for tasks) and Item 23 (Request help from students) have mean values 2.64, 2.63 and 2.52 respectively. The remaining four other items that received neutral responses from the teachers are Item 25 (Give commands), Item 32 (Compare between students' work), Item 21 (Introduce lesson/topic) and Item 33 (Testing purposes) with mean values 2.48, 2.43, 2.4 and 2.14.

\section{MICRO-FUNCTIONS OF BM UTILISED BY THE ENGLISH TEACHERS IN SOCIAL \& INTERPERSONAL DOMAIN}

TABLE 6. Teachers' Use of the Micro-functions of BM for Social \& Interpersonal Domain

\begin{tabular}{llcc}
\hline \multirow{2}{*}{ No } & Item & Mean & Std. Deviation \\
\hline 34 & I use BM to: & 3.31 & 1.021 \\
35 & Drablish rapport with the students & 3.06 & 0.957 \\
36 & Encourage students to be active during lesson & 2.99 & 1.004 \\
37 & Compliment students & 2.4 & 0.864 \\
38 & Create greater personal warmth & 3.03 & 1.029 \\
39 & Elicit students' participation & 2.98 & 0.998 \\
40 & Chat before the lesson to reduce students' anxiety & 2.96 & 1.055 \\
41 & Tell jokes & 3.13 & 1.015 \\
42 & Talk about learning & 2.87 & 1.009 \\
43 & Have unofficial interactions with the students & 3.46 & 0.969 \\
\hline
\end{tabular}

For the micro-functions of $\mathrm{BM}$ in this category, the teachers responded positively towards five out of the ten items. Item 43 (Have unofficial interactions), Item 34 (Establish rapport), Item 41 (Tell jokes), Item 35 (Draw upon shared expression) and Item 38 (Create greater personal warmth) all displayed mean values of 3.46, 3.31, 3.13, 3.06 and 3.03. However, majority of the teachers showed neutral responses for Item 36 (Encourage students 
to be active during lesson), Item 39 (Elicit students' participation), Item 40 (Chat before the lesson to reduce students' anxiety), Item 42 (Talk about learning) and Item 37 (Compliment) with mean values of $2.99,2.98,2.96,2.87$ and 2.4 respectively.

Based on the findings presented in Tables 4, 5 and 6, most of the English teachers in Pahang utilised the micro-functions of L1 mostly to teach the lesson content. For instance, to explain meanings or words, to elicit answers from the students and to explain certain terms. Meanwhile, majority of them, did not favor the use of BM to manage the classroom or to build social relation with the student.

\section{DISCUSSION}

The analysis from the survey demonstrated that majority of the English teachers in Pahang have utilised BM for certain micro-functions during their lessons. Although the teachers applied these functions of BM in each domain, it turns out that they did not employ all 43 micro-functions as listed in the framework. In particular, majority of them admitted using 17 micro-functions in Content Transmission, one micro-function in Classroom Management and five micro-functions in Social \& Interpersonal domain. In short, as shown in Tables 4,5 \& 6 , the English teachers employed 23 from the 43 micro-functions of BM.

The results clearly show that the English teachers in this study and other L2 teachers (from previous studies) utilised L1 to explain important aspects of the lesson such as to explain meaning of the words and sentences, grammar and to clarify or check comprehension. The utilisation of L1 is also noted in previous studies such as in secondary school context (Nur Shazwani \& Noreiny 2016; Cakrawati 2019) or tertiary level (Zhang 2018 and Alrabah et al. 2016). Teachers in these studies frequently used the micro-functions of L1 to assist them in teaching the lesson content. Apart from that, Noor Azaliya et al. (2019) and Nur Shazwani \& Noreiny (2016) discovered similar results in terms of teachers' application of BM for this specific domain.

In addition, the significant number of the micro-functions utilised by the teachers in present study corroborate with the outcomes of previous studies such as from Paker \& Karaagac (2015) and Shabir (2017). The former reported 17 micro-functions of L1 while Shabir reported 8 functions specially in content transmission and classroom management domain. In this study, the English teachers in Pahang utilised higher number of micro-functions compared to these two studies maybe because of two reasons. First, this study presents a more comprehensive list of the micro-functions of L1 in the L2 classroom. In contrast with the past studies, they incorporate less comprehensive list of the micro-functions of L1 compared to this current study. Furthermore, the classroom context as well as students' proficiency levels may affect the number of micro-functions employed by the teachers. For instance, both of the above studies were carried out at the university level, whereas this study was done at the secondary school level. Teachers at schools presumably use less functions of L1 to manage the class compared to teachers at university level.

There are a few reasons why English teachers had the inclination to use micro-functions of BM in the classroom. First, it may be affected by the demographic factor of this research. All schools that participated in this study are the national secondary schools where majority of the students are Malays and English is their second language. These students who mostly reside in rural or suburban areas are not exposed to the English language either at school or at home. This is because, the main language spoken in school and community is BM and the only place that provides them with English environment is during the English lessons at school. Therefore, coming from background with less exposure to the TL, they may have a little difficulty with words in the TL, thus further prompting teachers to resort to BM for a quick solution. 
Furthermore, majority of teachers also share similar L1 with the students and teachers from other races can speak BM since it is the national language of the country. Hence, switching to BM to supplement English lessons is unavoidable as the teachers need to address different proficiency levels of students in the classroom.

Although L1 could be used to assist L2 teachers to tackle the difficulties when dealing with students of various levels in learning the TL (Stern1992), there are a few implications that can be observed from its utilisation. The inconsistent use of L1 that has been reported, suggesting that L2 teachers including English teachers in Malaysia may not be informed of the guidelines available for them to use L1 in the classroom. Majority of the English teachers may not realise of other strategies available to address comprehension problem during L2 lesson. Thus, they may use L1 as it is convenient to do so since it does not require any preparation. To solve this ongoing issue, a more definitive framework of the micro-functions of L1 should be published to avoid excessive use of L1 by the teachers as reported in previous studies such as Paker \& Karaagac (2015) and Cakrawati (2019). Although limiting L1 may not be fruitful, it can be systematically and consciously in the L2 classroom by teachers(Cook 2001). Therefore, the implementation of a comprehensive guidelines for teachers to use BM should be done after a thorough examination by the ministry to ensure English teachers have the capacity to utilise it in the correct manner.

On the whole, this study suggests a few possible areas to be investigated with regard to the use of the micro-functions of BM to teach English. First, it is suggested to explore deeper on the effects of utilising BM towards English language proficiency. This can be done by conducting an action research to test out the framework of the micro-functions of L1 in the English classroom. Then, rather than focusing on BM as the L1, future research can be done to examine the micro-functions of other first languages for instance Mandarin or Tamil. In addition, do English teachers in primary schools use BM to scaffold the learning process as often as teachers in secondary schools? As a final remark, future studies should be carried out on these areas to increase teachers' awareness on the utilisation of BM in English classroom. They must be aware on how to use BM in the classroom so that their 'lapses' into the L1 can be identified, and they could adopt the right intervention when necessary. This is to ensure that eventually students will benefit by teachers' choice of using L1 during the lessons and to ensure that students are not overly dependent on L1 in the English classrooms.

\section{REFERENCES}

Abdullah Bhooth, Hazita Azman \& Kemboja Ismail. (2014). The role of the L1 as a scaffolding tool in the EFL reading classroom. Procedia - Social and Behavioral Sciences. 118, 76 - 84.

Ali Kutty Mohamed. (2011). The usage of Bahasa Malaysia in teaching English in the national primary schools: A survey of the English teachers' beliefs and practices in Kota Bharu. Master thesis. Open University Malaysia, Kuala Lumpur.

Alrabah, S., Shu-hua Wu,S-H., Alotaibi, A.M. \& Aldaihani, H.A. (2016). English Teachers' Use of Learners' L1 (Arabic) in college classrooms in Kuwait. English Language Teaching. 9(1), 1-11

Asmah Hj. Omar. (1982). Language and society in Malaysia. Kuala Lumpur: Dewan Bahasa dan Pustaka.

Atkinson, D. (1987). The mother tongue in the classroom: A neglected source? ELT Journal, 41(4): 241-247.

Auerbach, E.R. (1993). Reaxamining English only in the ESL classroom. TESOL Quarterly. 27(1), 9-32.

Azelin Mohamed Noor, Abdul Mutalib Embong \& Osaro Aigbogun. (2015). Using L1 in L2 classrooms: A case study among secondary school students of mixed English language proficiencies. International Journal of Arts \& Sciences. 8(2), 75-86.

Cakrawati, L.M. (2019). Exploring the use of learners' first language in English as a foreign language classroom. International Journal of Education. 11(2), 143-151.

Canagarajah, A.S. (1995) Functions of codeswitching in ESL classrooms: Socialising bilingualism in Jaffna, Journal of Multilingual and Multicultural Development. 16(3), 173-195.

Cook, V. (2001). Using the first language in the classroom. The Canadian Modern Language Review. 57, 402423.

Ellis, R. \& Shintani, N. (2014). Exploring language pedagogy through second language acquisition 
Elridge, J. (1999). Code-switching in a Turkish secondary school. ELT Journal. 50(4), 303-311.

Engku Haliza Engku Ibrahim, Mohamed Ismail Ahamad Shah \& Najwa Tgk. (2013). Code-switching in English as a foreign language classroom: Teachers' attitudes. English Language Teaching. 6(7), 139-150.

Farrel, T.S.C. (2019). 'My training has failed me': Inconvenient truths about second language teacher education (SLTE). The Electronic Journal for English as a Second Language. 22(4), 1-16.

Ferguson, G. (2003). Classroom code-switching in post-colonial contexts: Functions, attitudes and policies. AILA Review. 16, 38-51.

Flick, U. (2015). Introducing Research Methodology. A beginner's guide to doing a research project. London: Sage Publications Ltd.

Fortune, J. (2012). The forbidden fruit: Using the mother tongue in a Bogota university EFL programme. Colombia Applied Linguistics Journal. 14(2), 70-87.

Hamze, R.K. (2008). Teachers' and students' perceptions towards the use of Arabic in secondary level English language classrooms. Master thesis. American University of Sharjah, UAE.

Harbord, J. (1992). The use of the mother tongue in the classroom. ELT Journal. 46(4), 350-355.

Hazita Azman (2016). Implementation and challenges of English language education reform in Malaysian primarysSchools. 3L: Language Linguistics Literature, Southeast Asian Journal of English Language Studies. 22(3), 65-78.

Imran, S. \& Wyatt, M. (2015). Pakistani university English teachers' cognitions and classroom practices regarding their use of the learners' first languages. Asian EFL Journal. 17(1), 138-179.

Jerome, C., \& Samuel, M.S.G. (2017). Not quite what it seems: Rethinking the way we view teachers' beliefs and practices - A case study of a Malaysian ESL teacher. 3L: The Southeast Asian Journal of English Language Studies. 23(4), 1 - 14.

Joanna Tiffany Selamat. (2014). Code Switching in the Malaysian ESL classroom. Master thesis, University of Otago.

Krashen, S.D. (1981). Second language acquisition and second language learning. Oxford: Pergamon Institute of English.

Krejcie, R.V., \& Morgan, D.W. (1970). Determining sample size for research activities. Educational and Psychological Measurement. 30, 607-610.

Lasagabaster, D. (2013). The use of the L1 in CLIL classes: The teachers' perspective. American Journal of Content and Language Integrated Learning, 6(2), 1-21.

Leung, K.K. (2005). The role of the first language in second language learning for adult learners : A Vygotskian perspective. PhD Thesis. University of Technology, Sydney

Levine, G. S. (2012). Principles for code choice in the foreign language classroom: A focus on grammaring. Language Teaching. 47(03), 332-348.

Ma, L.P.F. (2016): Examining the functions of L1 use through teacher and student interactions in an adult migrant English classroom, International Journal of Bilingual Education and Bilingualism, 1-16.

Mahmud, S. (2018). Should teachers use L1 in EFL classroom? Journal of NELTA. 23(1-2), 26-39.

Nakatsukasa, K \& Loewen, S. (2014). A teacher's first language use in form-focused episodes in Spanish as a foreign language classroom. Language Teaching Research, 1-18.

Namba, K. (2005). What is Code-Switching? Retrieved Jan 2, 2019 from http://yayoi.senri.ed.jp/research/re10/Namba.pdf

Noor Azaliya Jumal, Asmaa AlSaqqaf \& Nik Zaitun Nik Mohamed. (2019). Code switching in Malaysian secondary ESL classroom: A preliminary study from Sabah. International Journal of Asian Social Science. 9(5), 327-334.

Noor Hayati Romli. (2015). The use of Bahasa Melayu in the English language classroom by 'non-optionist' English teachers. Master thesis, National University of Malaysia.

Nordquist, R. (2020). What Is a Second Language (L2). Retrieved Feb 4, 2020 from https://www.thoughtco.com/second-language-1691930.

Nur Shazwani Ja'afar \& Noreiny Maarof. (2016). Teachers' beliefs of code switching in the ESL classroom. Open Journal of Social Sciences. 4, 212-222.

Paker, T., \& Karagaç, O. (2015). The use and functions of mother tongue in EFL classes. Procedia - Social and Behavioral Sciences. 199, 111 - 119.

Paramesravan, M.D., \& Lim, J.W. (2018). Code-switching practices in a Malaysian multilingual primary classroom from teacher and student perspectives. Indonesian Journal of Applied Linguistics. 8(2), 254264 research. London: Routledge.

Shabir, M. (2017). Student-Teachers' Beliefs on the Use of L1 in EFL Classroom: A Global Perspective. English Language Teaching. 10(4), 45-52. 
Sipra, M.A. (2007). Bilingualism as Teaching Aid in a Language Class: L1 as a Facilitator in Teaching/Learning Process of L2 at Intermediate/Certificate Level. Unpublished PhD Thesis. National University of Modern Languages, Islamabad.

Stern, H. (1992). Issues and options in language teaching. Oxford: Oxford University Press.

Tsagari, D., \& Georgiou, E. (2016). Use of mother tongue in second language learning: Voices and practices in private language education in Cyprus. Mediterranean Language Review. 23, 101-126.

UNESCO Education Position Paper. (2003). Education in a multilingual world. United Nations Educational, Scientific and Cultural Organization. Retrieved on January 152019 from https://unesdoc.unesco.org/ark:/48223/pf0000129728.

Vygotsky, L. (1978). Interaction between. learning and development. In Gauvain \&. Cole (Eds), Readings on the development of children (pp. 34-40). New York: Scientific American Books.

Wu, Sipeng. 2018. Using the First Language in the Second Language Classroom. Retrieved on Jan 2, 2019 from http://dspace.library.uvic.ca/bitstream/handle/1828/9268/Wu_Sipeng_MEd_2018.pdf?sequence=1\&isA llowed $=\mathrm{y}$

Zhang, M. (2018). Collaborative writing in the EFL classroom: The effects of L1 and L2 use. System, 76, 1-12. 